\title{
Recommendations for the detection of Leptospira in urine by PCR
}

\author{
Recomendações para detecção de Leptospira em urina pela PCR
}

\author{
Paula M.A. Lucchesi ${ }^{1}$, Guillermo H. Arroyo ${ }^{1}$, Analía I. Etcheverría ${ }^{1}$, \\ Alberto E. Parma ${ }^{1}$ and Alfredo C. Seijo ${ }^{2}$
}

\begin{abstract}
In the present study PCR was applied to detect leptospires in human urine. Several approaches for sample processing were evaluated to optimize the detection of leptospires in urinemixed with this bacterium. Furthermore, some changes in the composition of the reaction mix were studied. No amplification was observed in acidic urine, therefore neutralization of the sampleimmediately after collection is strongly recommended. PBSgave better results than Tris or $\mathrm{NaOHas} \mathrm{neutralizing} \mathrm{reagents.} \mathrm{Freezing} \mathrm{and} \mathrm{thawing}$ of samples before processingyielded negative results. Elimination of epithelial cells, leukocytes and crystals by centrifugation at 3,000 rpm at room temperature increased sensitivity. In addition, both the washing step after collecting leptospires by centrifugation and the inclusion of $0.1 \%$ bovine serum albumin in the reaction mix minimized theinterference of other inhibitory compounds. These modifications were useful to improve the detection of Leptospira in urine by PCR.
\end{abstract}

Key-words: Leptospira. PCR. Urine. PCRinhibitors. Human.

\section{RESUM0}

No presente estudo, a PCRfoi utilizada para detectar leptospiras em urina humana. Diversas abordagens para processamento de amostra foram avaliadas para otimizar a deteç̧ão de leptospiras em urina misturada com esta bactéria. Além disso, algumas mudanças na composição da mistura de reação foram analisadas. Não se observou amplificação em urina ácida, conseqüentemente, a neutralização da amostra imediatamente após a coleta é fortemente recomendada. PBSapresentou melhores resultados que Tris ou NaOH como reagentes neutralizadores. Congelamento e descongelamento de amostras antes do processamento produziram resultados negativos. Eliminação de células epiteliais, leucócitos e cristais por centrifugação a 3.000rpm, à temperatura ambiente, aumentou a sensibilidade. Ademais, ambas, a etapa de lavagem após a coleta de leptospiras por centrifugação e a inclusão de albumina de soro bovino a 0,1\% na mistura de reação minimizaram a interferência de outros compostos inibidores. Essas modificações contribuíram para melhorar a detecção de Leptospira em urina através da PCR.

Palavras-chaves: Leptospira. PCR. Urina. Inibidores PCR. Humana.

Leptospirosis is a widespread disease that affects wild and domestic animals as well as humans ${ }^{12}$. There are several reports on the frequency of leptospirosis among livestock, wild animals and human beings in South America mainly in Argentina and Brazil ${ }^{41920}$. Humans may be infected indirectly from animals by contact with contaminated water, soil or mud in a moist environment, or by directinfection from urine, fresh carcasses or organs ${ }^{6}$.

There are many possible clinical presentations and courses of human leptospirosis. In the past two decades, an increasing number of cases of leptospiral pulmonary hemorrhages have been reported ${ }^{1921}$. As a consequence of the broad spectrum of nonspecific symptoms, leptospirosis can be misdiagnosed and clinical differential diagnosis is required between leptospirosis and severe influenza, viral meningitis, hepatitis, hemorrhagic fevers or nephritis, among other conditions ${ }^{6}$. A conclusive diagnosis cannot be made withoutlaboratory confirmation.

Most cases of leptospirosis are diagnosed by serology and the reference method is the microscopic agglutination test(MAT)

1. Laboratorio de Inmunoquímica y Biotecnología, Facultad de Ciencias Veterinarias, Universidad Nacional del Centro de la Provincia de Buenos Aires, Pinto 399,7000 Tandil, Argentina. 2. Servicio de Zoonosis, Hospital de Enfermedades Infecciosas "Dr. Francisco Javier Muñiz", Uspallata 2272, 1282 Buenos Aires, Argentina. Financial support: FONCYT, CIC and SECYT-UNCPBA. AEP and AIE are members of CIC and GHA is a member of the CONCET.

Address to: Dra. Paula Lucchesi. Laboratorio de Inmunoquímica y Biotecnología, Facultad de Ciencias Veterinarias, Universidad Nacional del Centro de la Provincia de Buenos Aires, Pinto 399, 7000 Tandil, Argentina.

Telefax: 54 2293-42-6667/42-2357.

e-mail: paulaluc@ vet.unicen.edu.ar

Recebido para publicação em 28/02/2003

Aceito em 22/12/2003 
although it is a complex test to control, perform and interpret ${ }^{12}$. Live cultures of all serovars required for use as antigens must be maintained. Another drawback is that antibodies are only detectable in blood approximately 5 to 7 days after the onset of symptoms.

Efforts for early diagnosis of leptospirosis are directed towards the detection of leptospires or their DNA or antigens in blood, cerebrospinal fluid, urine, and tissues. The techniques available are directexamination for leptospires, culture, detection of leptospiral antigens with antibodies, and detection of leptospiral DNA with homologous nucleic acid sequence probes, with or without amplification bypolymerase chain reaction $(\mathrm{PCR})^{616}$.

The PCRassay can be applied to selectivelyamplifyspecific DNA sequences bymore than $10^{6}$ fold ${ }^{17}$. Therefore, PCR is very useful for the rapid detection of organisms involved in acute infections. In fact, oligonucleotide primers have been developed by several research teams and applied for the specific detection of certain serovars of Leptospira ${ }^{1822} 23$. Gravekamp et al ${ }^{9}$ designed two pairs of primers for the specific amplification ofDNA of pathogenic leptospires. With some modifications, this method was applied in the analysis of several strains isolated in Argentina, from water, soil and human patients ${ }^{15}$.

Because endogenous substances presentin urine can inhibit PCR, we report several approaches for sample processing and some changes in the composition of the reaction mix to optimize detection of this bacterium.

\section{MATERIALS AND METHODS}

Bacterial strain and culture medium. Leptospira interrogans serovar pomona, donated by Dr. Gleyre Dorta de Mazzonelli (DILACOT-SENASA, Buenos Aires), was grown in EMJH medium ${ }^{511}$ at $27^{\circ} \mathrm{C}$ and periodically subcultured in fresh medium. This strain had been typed by the cross-agglutination absorption test ${ }^{24}$.

Urine mixed with leptospires. Aliquots were taken from a L interrogans serovar pomona culture in EMJH. Cells were washed twice in sterile distilled water by centrifugation at 12,000 rpm (microcentrifuge Sorvall RMC 14) for $20 \mathrm{~min}$ and resuspended in distilled water. After estimating the bacterial concentration by nephelometry, differentaliquots were added to urine from a healthy human to achieve concentrations of $1,000,10,000,100,000$ and 1 million bacteria per $\mathrm{ml}$.

Sample preparation for PCR. Samples of artificially inoculated urine were incubated at $40^{\circ} \mathrm{C}$ for $10 \mathrm{~min}$, to eliminate amorphous sediment, and then centrifuged at 3,000 rpm for 10 min atroom temperature to eliminate epithelial cells, leukocytes and crystals commonly present in urine. Leptospires were concentrated by centrifugation at 12,000 rpm for $20 \mathrm{~min}$, resuspended in $100 \mu \mathrm{l}$ distilled water and boiled for $10 \mathrm{~min}$. Two different volumes ( 10 and 35 $\mu$ l) of sample were tested by PCR in a total volume of $50 \mu \mathrm{l}$.

To this general procedure the following modifications were made in order to increase the sensitivity of the PCR.

Neutralization of urine: urine was neutralized to $\mathrm{pH} 7.6$ before adding the leptospires. Different solutions were used to achieve this $\mathrm{pH}$ : $0.1 \mathrm{M}$ Tris, $0.2 \mathrm{M} \mathrm{NaOH}$ and phosphate-buffered saline (PBS).
Freezing the urine: samples of urine seeded with leptospires were subjected to freezing at $-20^{\circ} \mathrm{C}$, before centrifugation. This modification was analyzed to determine if urine samples could be frozen before processing.

Washing the pellet of leptospires: after centrifuging to concentrate leptospires and before boiling, a washing step with distilled water was added.

Addition of bovine serum albumin (BSA) to the reaction mix: different concentrations of BSA, from 0.013 to $0.1 \%(\mathrm{w} / \mathrm{v})$, were added to the PCR reaction ${ }^{7}$ instead of gelatin.

PCR. The reaction mix was constituted by $50 \mathrm{mM} \mathrm{KCl}$, $10 \mathrm{mM}$ Tris- $\mathrm{HCl} \mathrm{pH} \mathrm{9.0,} \mathrm{0.1 \%} \mathrm{(v/v)} \mathrm{Triton} \mathrm{X-100,} \mathrm{2.5} \mathrm{mM} \mathrm{MgCl}_{2}$, $0.01 \%(\mathrm{w} / \mathrm{v})$ gelatin, $250 \mu \mathrm{M}$ each $\mathrm{dNTP}, 0.5 \mu \mathrm{M}$ each primer (G1, G2, B64-I, B64-II) , 1 UTaq DNA polymerase. Amplification was performed with primers which only detect pathogenic leptospires ${ }^{9}{ }^{15}$.

One drop of mineral oil was added to each tube to prevent evaporation. PCR amplifications were performed as follows: one initial cycle of $94^{\circ} \mathrm{C}$ for $180^{\prime \prime}$, one final cycle of $72^{\circ} \mathrm{C}$ for $240^{\prime \prime}$ and 38 cycles of $90^{\prime \prime}$ at $94^{\circ} \mathrm{C}$ (denaturing), $90^{\prime \prime}$ at $55^{\circ} \mathrm{C}$ (annealing) and $150^{\prime \prime}$ at $72^{\circ} \mathrm{C}$ ( extension) .

A positive control with leptospires in the absence of urine was always run, and results were referred to this.

Agarose gel electrophoresis. Ten $\mu l$ aliquots from each DNA amplification were analyzed by horizontal agarose gel electrophoresis and UV transillumination (300nm). Gel was constituted by $1.5 \%(\mathrm{~m} / \mathrm{v})$ agarose and $1.2 \mathrm{~g} / \mathrm{ml}^{-1}$ ethidium bromide in running buffer $(89 \mathrm{mM}$ Tris, $89 \mathrm{mM}$ boric acid, $1 \mathrm{mMEDTA}, \mathrm{pH}$ 8.0).

\section{RESULTS AND DISCUSSION}

Sample processing for PCR is critical and must be adjusted to the tissue, fluid, and species being tested. Several substances found in the various types of clinical material inhibit PCR, therefore positive specimens may go undetected because of false-negative results.

There are many references about inhibition of Taq DNA polymerase by several factors such us chelation of free magnesium ions, hemoglobin, bile salts, acidic polysaccharides from glycoproteins and extreme $\mathrm{pH}$ variations ${ }^{31013} 14$. Phenol and chloroform, often used for DNA extraction and purification, are also considered to be inhibitors ${ }^{10}$.

As a consequence of the presence of inhibitors, some DNA purification steps are necessary before performing PCR amplification. These purification steps increase the cost of the test as well as the time required for diagnosis. Therefore, we tested procedures and conditions for sample preparation which are quick and inexpensive, and do notrequire the use of expensive kits to purify DNA.

Some bacteria can be lysed during the storage of the urine and, as a result, their DNA can be lost with the supernatant after centrifuging to concentrate the microorganisms. Leptospira is sensitive to acid, at pH 6.8 or lower ${ }^{6}$. In this study, after only a 90 min contact with acid urine, leptospires could notbe detected 
by PCR. This emphasizes the need to neutralize the urine sample immediately after collection, to avoid losing bacterial DNA in the washing step. PBS buffer rendered better results than either $1 \mathrm{M}$ Tris or $0,2 \mathrm{M} \mathrm{NaOH}$ as neutralizing reagents ( Figure 1, lanes 1 to 3).

When the urine mixed with leptospires was frozen at $-20^{\circ} \mathrm{C}$ and thawed, before centrifugation steps, no leptospires could be detected by PCR (Figure 1, lanes 4 and 5). This suggests that when urine samples are going to be tested by PCR to detect leptospires, they have to be neutralized, and washed before storage at $-20^{\circ} \mathrm{C}$. In the case of samples that are not processed on the same day, they can be stored at $5 \stackrel{0}{ } \mathrm{C}$ until the following day, after neutralization.

The steps of sample preparation to improve the detection of leptospires in urine are summarized in Figure 2.

The optimum concentration of BSA used in the reaction mix for PCR was $0.1 \%$. (Figure 3, lanes 13 to 15 ). This protein

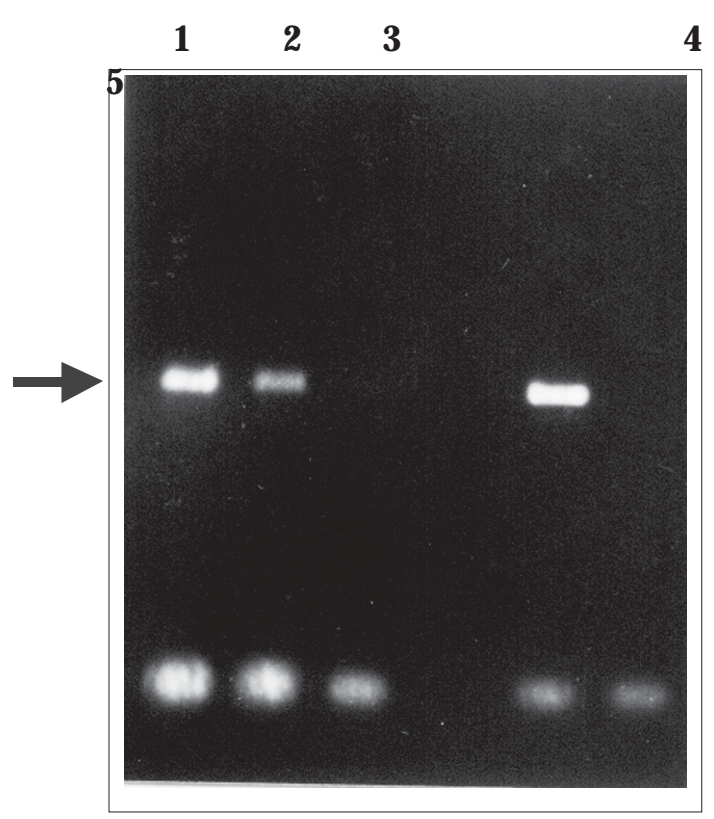

Figure 1 - Influence of the neutralizing agent on leptospiral DNA amplification from urine. Samples with: PBS (lane 1), $0.2 \mathrm{M} \mathrm{NaOH}$ (lane 2), $1 \mathrm{M}$ Tris (lane 3). Products corresponding to a sample frozen and thawed either after (lane 4) or before (lane 5) being processed for DNA extraction, were also electrophoresed.

plays a dual role since it can adsorb residual quantities of PCR inhibitors and also increases the stability in solution of Taq DNA polymerase.

A sample volume of $35 \mu \mathrm{l}$ in a $50 \mu \mathrm{l}$ PCR reaction mix rendered a band with a greater intensity than the use of $10 \mu \mathrm{l}$ of sample volume for PCR. However, there are cases in which increasing sample volume can result in increased inhibition of the enzyme, because inhibitory substances present in the sample also increase in quantity. The lower limit of detection was $10^{4}$ leptospires in $1 \mathrm{ml}$ of urine.

The results obtained in this work are important to be considered for the implementation of the PCR assay to detect leptospires in clinical samples of human urine. It is important

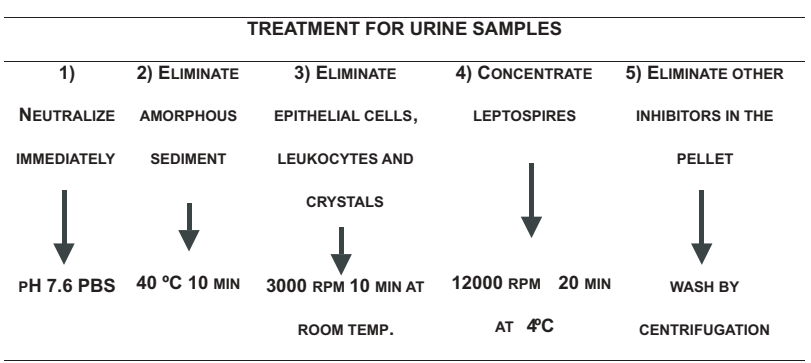

Figure 2 - Recommended steps for urine sample preparation.
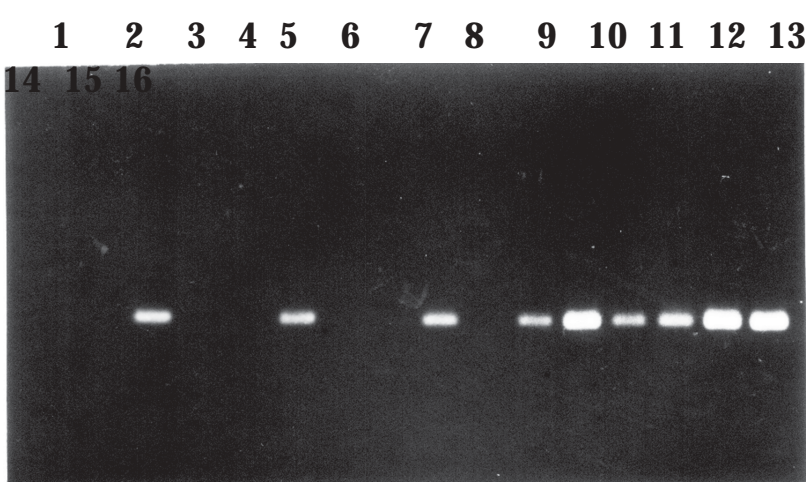

Figure 3 - Effect of bovine serum albumin (BSA) on the detection limit of leptospires in urine by PCR. Lanes 1, 2 and 3 correspond to urine containing $10^{4}, 10^{5}$ and $10^{6}$ leptospires/ml, respectively, with $0.013 \%$ BSA added to the reaction mix; lanes 4, 5 and 6: with $0.025 \%$ BSA; lanes 7, 8 and 9: with $0.05 \%$ BSA; lanes 10, 11 and 12: with $0.078 \%$ BSA; lanes 13, 14 and 15: with $0.1 \%$ BSA; lane 16: positive control (amplification of urine-free leptospiral DNA).

to note that an internal control for the amplification reaction is necessary because inhibitory substances can vary among patients or between samples from the same patient.

\section{ACKNOWLEDGEMENTS}

The authors thank M.R. Ortiz for her technical assistance.

\section{REFERENCES}

1. Alexander $\mathrm{AD}$. Leptospira. In: Lennette EH, Spaulding E, Truant JP (eds) Manual of clinical microbiology, $2^{\text {nd }}$ edition, American Society for Microbiology, Washington, DC, p. 347-354, 1974.

2. Alston JM, Broom JC. Leptospirosis in Man and Animals. Livingstone Ltd, London, p.277-300, 1958.

3. Bej AK, Mahbubani MH. Thermostable DNA polymerase for in vitro DNA amplification. In: Griffin H, Griffin A (eds) PCR technology: current innovations, CRC Press, London, p. 219-237, 1994.

4. Costa E, Costa YA, Lopes AA, Sacramento E, Bina JC. Formas graves de leptospirose: aspectos clínicos, demográficos e ambientais. Revista da Sociedade Brasileira de Medicina Tropical 34:261-267, 2001.

5. Ellinghausen Jr HC, McCullough WC. Nutrition of Leptospira pomona and growth of 13 other serotypes: a serum-free medium employing oleic albumin complex. American Journal of Veterinary Research 26:39-44, 1965.

6. Faine S. Leptospira and Leptospirosis. CRC Press, Inc, Boca Raton, Florida, 1994.

7. Forbes BA, Hicks KE. Substances Interfering with Direct Detection of Mycobacterium tuberculosis in Clinical Specimens by PCR: Effects of Bovine Serum Albumin. Journal of Clinical Microbiology 34:21252128, 1996. 
8. Gonçalves AJ, de Carvahlo JE, Guedes e Silva JB, Rozembaun R, Vieira ARM. Hemoptise e sindrome de angustia respiratoria do adulto como causas de morte na leptospirose: mudanas de padroes clinicos e anatomopatologicos. Revista da Sociedade Brasileira de Medicina Tropical 25:261-270, 1992.

9. Gravekamp C, Van de Kemp H, Franzen M, Carrington D, Schoone GJ, Van Eys GJJM, Everard COR, Hartskeerl RA, Terpstra WJ. Detection of seven species of pathogenic leptospires by PCR using two sets of primers. Journal of General Microbiology 139:1691-1700, 1993.

10. Greenfield L, White TJ. Sample preparation methods. In: Persing D, Smith T, Tenover F, White TJ (eds) Diagnostic molecular microbiology: principles and applications, ASM Press, Washington DC, p. 122-137, 1993.

11. Johnson RC, Harris VG. Differentiation of pathogenic and saprophytic leptospires. 1. Growth at low temperatures. Journal of Bacteriology 94:2731, 1967.

12. Levett PN. Leptospirosis. Clinical Microbiology Reviews 14:296-326, 2001.

13. Mahbubani MH, Bej AK. Applications of polymerase chain reaction methodology in clinical diagnostics. In: Griffin H, Griffin A (eds) PCR technology: current innovations, CRC Press, London, p. 307-326, 1994.

14. Panaccio M, Lew AM. Direct PCR from whole blood using formamide and low temperatures. In: Griffin H, Griffin A (eds) PCR technology: current innovations, CRC Press, London, p. 151-157, 1994.

15. Parma AE, Seijo A, Lucchesi PM, Deodato B, Sanz ME. Differentiation of pathogenic and non-pathogenic leptospires by means of the polymerase chain reaction. Revista do Instituto de Medicina Tropical de São Paulo 39:203-207, 1997.

16. Saengjaruk P, Chaicumpa W, Watt G, Bunyaraksyotin G, Wuthiekanun V, Tapchaisri P, Sittinont C, Panaphut T, Tomanakan K, Sakolvaree Y, ChongsaNguan M, Mahakunkijcharoen Y, Kalambaheti T, Naigowit P, Wambangco MAL, Kurazono H, Hayashi H. Diagnosis of Human Leptospirosis by
Monoclonal Antibody-Based Antigen Detection in Urine. Journal of Clinical Microbiology 40: 480-489, 2002.

17. Saiki RK, Gelfland DH, Stoffel S, Scharf S, Higuchi SJ, Horn R, Mullis GT, Erlich HA. Primer-directed enzyme amplification of DNA with a thermostable DNA polymerase. Science 239:487-491, 1988.

18. Savio ML, Rossi C, Fussi P, Tagliabue S, Pacciarini ML. Detection and identification of Leptospira interrogans serovars by PCR coupled with restriction endonuclease analysis of amplified DNA. Journal of Clinical Microbiology 32:935-941, 1994.

19. Seijo A, Coto H, San Juan J, Videla J, Deodato B, Cernigoi B,García Messina O, Collia O, Bassadoni D, Schtirbu R, Olenchuk A, Mazzonelli GD, Parma AE. Lethal leptospiral pulmonary hemorrhage: an emerging disease in Buenos Aires, Argentina. Emerging Infectious Diseases 8:1-4, 2002.

20. Seijo A, Draghi G, Dorta de Mazzonelli G, Mazzonelli J, Stiebel C, Argento E, Caminoa R, Deodato B y colaboradores de la CCLA. Informe sobre leptospirosis en la República Argentina. Fundación Mundo Sano, Bs As. Serie Enfermedades Transmisibles, publicación monográfica 3, 2002.

21. Trevejo RT, Rigau-Perez JG, Ashford DA, McClure EM, Jarquin-Gonzalez C, Amador JJ, de los Reyes J0, Gonzalez A, Zaki SR, Shieh WJ, McLean RG, Nasci RS, Weyant RS, Bolin CA, Bragg SL, Perkins BA, Spiegel RA. Epidemic leptospirosis associated with pulmonary hemorrhage-Nicaragua, 1995. Journal of Infectious Diseases 178:1457-1463, 1998.

22. Van Eys GJJM, Gravekamp C, Gerritsen MJ, Quint W, Cornelissen MTE, Ter Schegget J, Terpstra WJ. Detection of leptospires in urine by polymerase chain reaction. Journal of Clinical Microbiology 27:2258-2262, 1989.

23. Woodward MJ, Sullivan GJ, Palmer NMA, Woolley JC, Redstone JS . Development of a PCR test specific for Leptospira hardjo genotype bovis. Veterinary Record 128:282-283, 1991

24. World Health Organization. Classification of leptospires and recent advances in leptospirosis. Bulletin World Health Organization 32:881-891, 1965. 